\title{
Dead Letters? The Uniform Civil Code through the Eyes of the Indian Women's Movement and the Indian Supreme Court*
}

\author{
TANJA HERKLOTZ \\ tanja.herklotz@rewi.hu-berlin.de
}

\section{Introduction}

The question of whether a Uniform Civil Code (UCC) for the whole Indian territory should replace the existing religious personal law system, which India, like other post-colonial states, maintains, has acted as a catalyst for discourses on national integration, modernity, secularism and more recently, gender equality. From an equality point of view the pluralistic personal law system is perceived as problematic, as firstly, it provides for different laws for members of different religious communities and secondly, it treats men differently from women. Here, the introduction of a secular Uniform Civil Code could provide for a solution. On the other hand, the global trend among academics as well as International Organisations, Non-Governmental Organisations and human rights activists seems to be one that moves away from the "state-centred orthodoxy of rule of law" towards the acceptance of "normative orderings beyond the state's reach" (Sezgin 2010b: 1, 2). This paradigm shift acknowledges that "[a]bout $80 \%$ of the people in the developing world, particularly in Asia and Africa, are believed to be using informal or non-state legal systems" (Sezgin 2010a: 5).

If legal pluralism is accepted as a fact, then the idea of article 44 of the Indian Constitution, a Directive Principle of State Policy that urges the state to introduce a UCC, seems somewhat out of place. Has this constitutional goal of a uniform set of laws therefore lost its meaning? This question is assessed here through an analysis of the discourse around article 44 among two different entities: the Indian women's movement and the Indian Supreme Court. Both actors play a central role within the state-the court as one of the "classical" three powers, and the women's movement as a part of civil society that undoubtedly 
influences the socio-political dynamics of a democracy. Both entities are believed to be avant-garde and activist. Both strive to fulfil a vision of a rights expansion for vulnerable groups.

To be sure, "the Indian women's movement" is not a homogenous bloc with only one standpoint; rather it is heterogeneous, consisting of a variety of sub-groups along the lines of identities other than gender. The question of who can and should represent whom regarding "women's concerns" is a central one and it is clear that the notion of "women" as a category carries its own problems (Krishnaraj 1998: 393). Nevertheless, broader trends and positions with regard to the personal laws and the UCC can indeed be identified when looking at different women's groups and activists over a time span of about four decades. Therefore, for the purpose of this paper it seems legitimate to speak about "the women's movement", especially when juxtaposing it with the Indian judiciary. Indeed, the terminology of "the Supreme Court" poses similar questions, bearing in mind that judgments may be rendered by smaller or larger benches and that they are shaped by the judicial attitudes and ideological preferences of the individual judges (McCammon \& McGrath 2015: 132). But here likewise, the trends over a few decades allow for general statements about "the court" itself.

When comparing the two protagonists against the background of their engagement with the UCC, the rhetoric and argumentation used is astonishingly different. While during the 1970 s and $1980 \mathrm{~s}$, the common Code was an attractive option for both actors, in recent decades the position of the women's movement has shifted drastically from the call for a UCC. The court, instead, has kept its call for the Code-at least on a rhetorical level. In a variety of judgments it calls upon the legislator to introduce the common Code, thereby, interestingly, drawing mostly on arguments of modernity and national integration rather than gender equality. Against the background of the abovementioned paradigm shift towards the acceptance of legal pluralism, does this mean that the women's movement-which today is warning about a legislative top-down approach and suggesting reforms from within the religious communities has seen the signs of the time more clearly than the court?

This paper argues that despite their different rhetoric, both entities have in actual fact accepted legal pluralism. But while the women's movement has turned away from the constitutional provision of article 44 and openly declares the UCC unfeasible, the Supreme Court still pays lip service to the constitution in its call for the Code, while 
demonstrating no action to push the project further. It has been reluctant in declaring personal laws unconstitutional and has not exhibited any of the activism it performed in cases regarding other Directive Principles. Calling for the UCC is therefore mere rhetoric.

Nevertheless, this does not mean that article 44 is a "dead letter". Its essence-uniformity and equality-is gradually being carried out through other means. It is not being achieved through an allencompassing legislative reform, but through a gradual shift in legislation, practice and judicial interpretation. The women's movement pushes for these changes through its lobbying on the state level as well as its work on the ground in collaboration with religious communities. And the judiciary (High Courts and Supreme Court) today actually practises precisely those piecemeal-attempts that in 1985 in the Shah Bano case the Supreme Court so vehemently warned about. It reinterprets personal laws on a case-by-case basis and thereby assimilates their content.

The paper will first provide a brief overview of the history of article 44. It will then engage with the discourse around the UCC among the women's movement, hereby drawing on publications and website entries of women's groups as well as (feminist) scholarship that reflects on the women's movement and personal conversations with women who were or are active in the movement. Subsequently, it will engage with the discourse around article 44 within the Supreme Court, drawing on decisions that refer-usually in the form of obiter dicta-to a potential UCC. Finally, it will compare and contrast the two discourses and indicate a more in-depth analysis that takes into account both rhetoric and action.

\section{The Promises of Article 44}

The UCC is a counter concept to the existing personal law system, according to which certain family and property matters (marriage, divorce, maintenance, guardianship, adoption, succession and inheritance) of Hindus, Muslims, Parsis and Christians as well as Jews are governed by their respective religious laws. ${ }^{1}$ These laws are partly codified and partly uncodified and customary. The idea of replacing this system with a uniform Code has promised and seems to mean different things to different entities: Gender equality to the women's movement and national integration, secularism and modernity to the Supreme Court. 
Personal Laws and the UCC: Historical Background

While personal laws per se are an ancient phenomenon, the Indian system of personal laws in its present form dates back to the late 18th century when the administrators of the East India Company exempted parts of religious law from the purview of their regulatory action (Bajpai 2011: 183; Parashar 1992: 62; Menski 2003: 161). Marking the intervention of state-centric legal regulation under increasing colonial supervision, the Warren Hastings Plan of 1772 provided that Hindus and Muslims were to be governed by their own laws in disputes relating to inheritance, marriage, caste and other religious usages and institutions. Granting the colonised communities some degree of autonomy helped the colonisers to dissipate the opposition to the colonial rule and was therefore administratively convenient (Mullally 2004: 676). However, although in the area of penal law the British unified the laws with the Indian Penal Code in 1862, a similar step towards the unification of civil laws with regard to the family was not taken (Menski 2008: 224). What happened, though, was that the colonisers modified the personal laws through the interpretation by British judges (Mann 2007), which made them a "curious amalgam of religious rules and English legal concepts" (Parashar 1992: 307) and created what used to be called Anglo-Hindu law (Derrett 1957) and Anglo-Muhammadan law.

The demand for a secular Uniform Civil Code grew with the Indian independence movement as such a Code was supposed to contribute to unity among the communities and to strengthen a common front against British domination (Austin 2001: 17). The debate continued after independence and during constitution-making (Mansfield 2005). The assumption of the proponents of the Code was that for the purposes of nation-building and modernisation, India required the secularisation of law (Baird 2005: 19-20; Parashar 1992: 230-1). Arguments against the UCC focused on the right to religious and cultural freedom, the aspects of community identity and the protection of religious minorities, especially against the background of India's partition and the violent months that followed, which brought about a feeling of insecurity and anxiety especially among Muslims (Agnes 2011: 150; Parashar 1992: 231). The issues of gender-justice and equality were not very prominent during this period. 


\section{Article 44 as a Compromise}

The "intricate compromise" (Menski 2008: 221), which advocates and opponents of the UCC agreed upon in the end, was to mention the Code among the Directive Principles of State Policy. Article 44 reads: "The State shall endeavour to secure for the citizens a uniform civil code throughout the territory of India". What such a Code would look like, whether it would replace the personal laws or simply complement them, or even whether such a Code would accommodate gender justice is left open by the constitutional provision. Contrary to the Fundamental Rights in part III of the constitution, the Directive Principles contained in part IV "shall not be enforceable by any Court" while nevertheless being "fundamental in the governance of the country" (article 37). This means that they do not directly create any justiciable rights in favour of individuals, nor can a law be declared unconstitutional on the sole ground that it contravenes any of the Directive Principles, but they still function as "instruments of instructtion to the Government" (Das Basu 2013: 158).

Challenging the constitutionality of the personal laws with an alleged violation of article 44 is therefore not possible, but it is not completely absurd either, as the Supreme Court in other cases has "read" Directive Principles "into" Fundamental Rights. ${ }^{2}$ While those cases were certainly different in the sense that they concerned social or economic rights, and not a legislative mandate such as article 44, it is not beyond the imagination that the Supreme Court could increase the importance of article 44 through jurisprudence. The court could stress the importance of the Directive Principle, reading it in connection with the right to equality (article 14 and 15) or the principle of secularism enshrined in the constitution's preamble.

A debate about the constitutionality of the personal laws against the background of the right to equality arose shortly after independence. According to article 14 "[t]he State shall not deny to any person equality before the law or the equal protection of the laws". According to article 15 "[t]he State shall not discriminate against any citizen on grounds only of religion, race, caste, sex, place of birth or any of them". With regard to the personal laws, these provisions play a role in a two-fold manner: firstly, they treat different religious communities differently, and secondly, they treat men and women within the same religious community differently. The alleged unconstitutionality was debated in 1952 in Narasu Appa Mali. ${ }^{3}$ The claimant challenged the Bombay Prevention of Bigamous Marriages Act, 1946, which imposed monogamy on Hindus, whereas Muslim personal law allowed Muslim 
men to practise polygamy. The Bombay High Court came to the conclusion that personal laws were not "laws in force" within the purview of article 13 of the constitution. As the constitution itself recognised the existence of separate personal laws, it seemed to leave them "unaffected" (Parashar 1992: 204-6). Hence, personal laws were not void even when they came into conflict with the provision of equality under the constitution. In a later decision the Supreme Court held a different view, declaring in an obiter dictum that personal laws "must be consistent with the Constitution lest they became void under article 13 if they violated fundamental rights." 4

\section{Public Discourse and the Media}

Time and again the Uniform Civil Code features in the Indian media and while there is some doubt about its feasibility (De 2013), many authors still argue in favour of its introduction. Public debate and the media draw on topics similar to those that shaped the Constituent Assembly debates: national integration and "communal harmony", secularism and modernity. Personal laws have frequently been and continue to be depicted as problematic and in need of reform.

Interestingly, while during the British rule it was especially practices of Hindu law, such as child marriage, sati and the ban on widow remarriage that were regarded as societal evils and in need of reform, the focus of critique later shifted to Muslim law (Kishwar 1986: 5-6). In particular, with the reforms of Hindu personal law in the 1950s, Hindu law came to be seen as modern (and more gender-just), while Muslim personal law was and still is depicted as backward and uncivilised. A heyday for this anti-Muslim rhetoric was the mid-1980s, a time of communalised tension fuelled by the Supreme Court's decision in Shah Bano. ${ }^{5}$ In this case, the court granted post-divorce maintenance to a divorced Muslim woman, using extremely biased language and defaming Muslim personal law. Nadja-Christina Schneider, who evaluated the English speaking media in India before and after the Shah Bano case, shows how undifferentiated Muslim personal law and the Muslim community were depicted. The media created the impression that the Muslim minority comprises a homogenous "mass of fanatics" and potentially violent "fundamentalists" from which only a small number of "modern" or "liberal" Muslims sets itself apart (Schneider 2005: 196). Often the Indian press (deliberately) confused Muslim personal laws with Islamic criminal law, thereby reinforcing the picture of Muslim law as backward and barbaric (Schneider 2005). 
Women's rights and gender equality for a long time only played a secondary role in the media and in the public debate around the UCC. The Working Group for Women's Rights (WGWR) held that in a debate revolving around dichotomies of nation vs. community, individual vs. collective, and majority vs. minorities "women as a category are rendered invisible" (WGWR 1996: 1182). This is astonishing, as women's rights groups were actually formed long before independence and the women's movement demanded a Uniform Civil Code as early as 1937 (Menon 2012: 151). From the 1960s onwards the discourse around the UCC was sporadically linked to women's rights and later (especially in the 1980s) women's groups began to vehemently push for the Code as a means to ensure gender-just laws for women in all religious communities (Sunder Rajan 2008: 85). To be sure, in recent times, the media has provided a more differentiated picture than in the 1980s when it comes to personal laws: More commentators focus on aspects such as justice and gender equality and pay attention to all personal laws, rather than putting their sole focus on the Muslim community (Schneider 2005: 264). Nevertheless, the public debate tackles the gender dimension of the personal laws only superficially. Only feminists, states Nivedita Menon, have openly denounced the "constitutionally enshrined inequality between men and women" (Menon 2012: 151).

\section{Article 44 in the Discourse of the Women's Movement}

Not surprisingly, in their engagement with the personal laws, Indian women's rights activists and women's groups focus on "legal equality for women" (Parashar 1992: 203). To a large degree, they have had a critical view of the personal laws - regarding them as being formed in patriarchal societies and pointing out that many provisions discriminate against women. Against this background, the UCC has long held the promise of providing for a gender just reform and the women's movement has long used the reference to article 44 along with the right to equality and secularism to push for legislative changes.

Interestingly, however, this position has shifted drastically over time. This was, on the one hand, due to a "hijacking" of the topic by Hindu nationalist parties, with which many women's activists did not want to be associated. On the other hand, ideas of intersectionality gained importance in feminist scholarship and led to a rethinking among activists. Today, most women's groups question the feasibility of an all-encompassing UCC that is "imposed" with a top-down 
approach. Instead they present more nuanced approaches regarding how to reform the personal laws from within the communities or how to provide for secular options that can coexist with the personal laws. These positions are supported by the movement's work on the ground, in collaboration with religious communities. Article 44-taken literallyhas completely lost its appeal.

\section{The Women's Movement}

India's contemporary women's movement is often regarded as the "third" women's movement, following the social reform movement of the 19th century with its ambition to improve rights for women and the engagement of women during the struggle for independence. Its beginning is usually located in the Emergency (1975-76), although numerous formal and informal women's groups concerned with feminism and women's rights were already formed in the early 1970 s (Agnihotri 2001). Throughout the decades the movement has addressed a variety of issues, such as sexual oppression of women, sexual harassment and rape, dowry and dowry-related crimes, property and succession, health and women's reproductive rights, to mention but a few examples (Sen 2014; Kumar 1993). The personal laws have featured as an issue of debate throughout the decades.

Not only in terms of the topics engaged with, but also in terms of forms of activism and campaigning, the movement is quite diverse and has witnessed some shifts over time: From the formation of autonomous women's groups in the 1970s (autonomy is understood here to refer to various groups, including men, religious groups, political parties or state institutions, see Sen 2014: 335), to united fora and coordinated platforms in the 1980s (Agnihotri 2001), to what is often called an "NGOisation" of the movement in the 1990s (Sen 2014: 337). Methods of agitation shifted from public campaigns, demonstrations, and street theatre (Kumar 1993: 143) towards new strategies of networking, gender-sensitisation training and advocacy (Sen 2014: 337). Women's groups have engaged with "the law" on various levels, most importantly through campaigning for legislative changes and taking up individual cases to follow them through the intricacies of the courts (Kumar 1993: 143).

\section{Feminist Critique of the Personal Laws}

Featuring only as one issue among many, the personal laws, nevertheless, have remained a relevant topic for the women's movement 
over time. Debates among women's groups as well as within feminist scholarship are distinct from the public discourse, not only in the sense that they focus on the gender dimension, but also in the sense that they look at the personal laws of all religious communities, rather than singling out the Muslim personal law as problematic. They stress that despite the differences among them, the personal laws of all communities contain aspects that contradict the right to equality. While it should not be undermined, that there exist women's groups-for instance those affiliated with Hindu nationalist parties-to which this might not apply, the general trend seems to be one that tries to explicitly disrupt the notion of only Muslim law being archaic and antiwomen.

To provide a detailed list of the discriminatory aspects of the different personal laws is beyond the capacity of this paper. In order to be complete, such a list would have to go beyond the wordings of the provisions as stated in certain acts and beyond the dominant customary law, and take into account the laws as they are interpreted by the courts and as they are practised on the ground. For the purpose of this paper one would also have to look at changes over time and engage with provisions that used to be discriminatory and therefore formed part of the debate among the women's movement, but have-partly as a reaction to the feminist struggle - been amended in order to comply with Fundamental Rights. Scholars like Parashar (2005), Jenkins (2009) and Agnes (2011) and women's rights organisations like Saheli and the Working Group on Women's Rights have engaged in detail with the problematic aspects of the personal laws and the dynamics around them. Here it shall suffice to give a few examples.

A woman under Hindu law cannot adopt a child in her own name. Nor has she guardianship rights over her child who is above five years of age. Until 2005 daughters could not be coparceners of the Hindu Joint Family property. But even after the Hindu Succession (Amendment) Act from 2005 unequal provisions remain. For instance, when a female Hindu dies intestate, any property she has inherited from her husband will pass to the husband's heirs, while such a provision does not exist in respect of men who die intestate. Muslim husbands are entitled to practise polygamy while Muslim wives can only have one husband. A Muslim husband can dissolve the marriage unilaterally through (triple) talaq, while it is much harder for the wife to achieve a divorce. The women's share under Islamic inheritance law remains less than that of her male counterpart. The Indian Succession Act of 1925 gives Christian mothers no right in the property of their deceased 
children who have left no will. The property is instead inherited by the father, or-if he is not alive-by the siblings. For a long time, Christian Personal Law was also subject to debate because Section 10 of the Indian Succession Act stipulated that while a husband could get divorced only on the ground of adultery, the wife had to prove adultery plus an additional divorce ground such as cruelty or desertion. This was changed in the Indian Divorce (Amendment) Bill in 2001. Parsi law until 1991 discriminated between female and male descendants.

Overall, the Working Group on Women's Rights (WGWR) concluded in 1996: "All personal laws are highly discriminatory against women since they are based on an interpretation of religion that sanctions patriarchy and resists democratic and egalitarian relations between men and women outside as well as within the family" (WGWR 1996: 1181). Feminist scholars criticise the fact that personal laws are rarely amended in order to adapt to social change and mostly remain "fossilised in the name of religious inviolability" (Parashar 2005: 307). Now, this feminist critique of the personal laws might lead to the assumption that feminist scholars and women's rights activists favour the enactment of a secular Uniform Civil Code. While this was indeed the case in the 1970s and 1980s, interestingly it no longer is. The call for a UCC has now mostly been given up as a feasible option.

\section{Calling for a UCC}

While a few early demands for a UCC from the side of the women's movement had already been made in the pre-independence era ${ }^{6}$, the issue became a hot topic among the nascent women's movement of the 1970s. At this time, there was a general position among the movement to support the introduction of the UCC. In these years, the feminist pro-UCC position (in order to achieve gender justice) was not consciously articulated as distinct from the "mainstream discourse of national integration", but rather seemed to be "part of the same project" (Menon 1998: 251). This intersection of the arguments of equality and nationalism can also be seen in the report of the Committee on the Status on Women in India. ${ }^{7}$ Calling for the "expeditious implementation" of a Uniform Civil Code, the report does mention the gender-inequality of the personal laws, but at the same time regards them as being "against the spirit of national integration". The absence of a UCC is depicted as "an incongruity that cannot be justified with all emphasis that is placed on secularism, science and modernisation". 
The standpoint became more differentiated during the 1980s. While the call for the UCC at first remained the dominant position among activists and women's groups, many in the movement began to rethink their argumentation. For Menon (1998: 252) the period of mass discontent following the state of emergency marked the beginning of a rethinking among feminists, as it became clear that the "national integrity" argument was a farce, in that it was primarily Hindu integrity that was to be protected. Women's rights activists now intended to make clear that the Code they envisioned was distinct from the one that Hindu nationalist parties like the Bharatiya Janata Party (BJP) aimed at. While the women's movement had a secular gender-just UCC in mind, went the argument, the BJP would only use the name of a uniform Code in order to impose Hindu law on the whole population. Kishwar (1986: 13) in her magazine Manushi - $A$ Journal about Women and Society, calls women's organisations to action in order to draft a UCC based on "the principles of fairness and equality" lest the UCC becomes a Hindu project. The UCC that the BJP aims at, she warns, would be "'common' only in name, common in the sense that it will be imposed on everyone" (Kishwar 1986: 10).

The Delhi-based women's group Saheli argues similarly. Regarding all religions as oppressive "products of a less developed society", the introduction of a UCC is seen as the only solution to get rid of the "continued exploitation based on religion" (Saheli 1986). Secularism, in the view of the organisation, stands for modernity, growth and development and is necessarily connected to gender justice. Hence, a UCC is needed so that women no longer have to "live with a medieval concept of family" (Saheli 1986). In a similar vein as Kishwar, Saheli distances itself from the rhetoric of the "Hindu Communalists", whose rhetoric has led to a "misunderstanding" of the demand for a UCC (Saheli 1986). There were also minority women who favoured the enactment of a UCC during the 1980s. A female Muslim journalist called for the introduction of a UCC in the Times of India (see Kishwar 1986: 5) and the national convention of the Young Christian Women's Association (YCWA) in 1982 and in 1986 passed resolutions in favour of a UCC (Parashar 1992: 242).

Not only calling the parliament to act, but also taking matters into their own hands, a variety of different actors-among them many women's groups-worked on the possible content of a UCC and introduced draft codes into parliament (Agnes 2011: 177). Parashar envisions a gender-just UCC being built on three distinct pillars: firstly, "the best pro-women elements from the existing personal law 
systems", secondly, "desirable features from the civil laws of other countries", and thirdly, provisions of "international conventions and agreements" (Parashar 1992: 256-60). Overall, there was a strong demand among feminists and women's rights groups for the implementation of a UCC. Until the mid-1980s the women's movement was relatively united and it did not seem unlikely at this point in time that it would push parliament to take the project further.

\section{Rethinking the Agenda}

In the late 1980 s a slow and gradual paradigm shift set in, which influenced the position of the women's movement. There were several interconnected reasons for this shift. Firstly, while earlier feminists and women's rights activists distanced themselves from the position of the Hindu right, but kept their call for a UCC, it seems that at a certain point they were no longer willing or capable to follow this path. Events like the Supreme Court's ruling in the Shah Bano case in 1985 and the demolition of the Babri Masjid in Ayodhya in 1992 led to a "communalised" climate, in which the women's movement no longer wanted to share the same goal as the BJP. Secondly, the idea of "intersectionality" gained importance and a strict dichotomy between religious freedom and women's rights did not seem adequate any more.

The Shah Bano case dealt with a claim for maintenance filed by a divorced Muslim woman against her ex-husband. The Supreme Court in its judgment rejected the ex-husband's claim that under Muslim personal law he was not required to pay maintenance after the iddat period (roughly three months) and after having paid her an amount as mehr (a form of dower). Instead, the judges held that the secular provision of Section 125 Code of Criminal Procedure (CrPC) applies to all citizens irrespective of their religion and hence overrides the personal laws (for a detailed description of the case see Bajpai 2011: 180). The judgment led to severe agitation among the Muslim population, stirred further by the Muslim Personal Law Board, which regarded the judgment as an interference by the court in Muslim personal law (Bajpai 2011: 180-1). Shortly after the ruling, the Rajiv Gandhi government enacted a law that took Muslims out of the purview of Section 125 CrPC: the Muslim Women (Protection of Rights on Divorce) Act (MWA). Many saw this act as a step away from the UCC, as one religious community was precisely taken out of the purview of a secular law, which was previously applicable to all. Feminist scholarship and women's rights groups criticised the 
legislation as "a glaring defeat of principles of gender justice and secularism" (Agnes 2011: 157). But critique also came from Hindu nationalists, who commented that the act was "separate legislation exclusively for Muslims" and it afforded "preferential treatment" to the minority (Dhavan 2001: 317-8).

The fact that in this context the BJP made the topic of the UCC part of its own political agenda has led to much critique. Scholars have accused the party for using the UCC as a "political weapon" (Kishwar 1993: 3), and as a tool to silence religious minorities (Mullally 2004: 673) and to "chastise" them "for not emulating the Hindu example" (Dhavan 2001: 317). It is this supposed "hijacking of the secular agenda" (Mullally 2004: 673) that ultimately led feminists and women's groups to disassociate themselves from the call for a UCC. In a tense political climate, the women's rights groups that traditionally had associated themselves predominantly with the political left were no longer willing or capable to share this "uneasy alliance with Hindu right-wing groups" (Agnes 2012: 35), fearing that their pressing for a UCC would now strengthen the Hindu nationalists. Some women's groups maintained their position but changed their terminology, dropping the term "uniform", and now speaking of a "common", a "genderjust" or an "egalitarian" civil Code. Saheli, for instance, began to speak of an Egalitarian Civil Code (ECC), making clear that the Code of the BJP and its own Code "connote two completely different concepts" (Saheli 1995). Most groups, however, gave up their call for a UCC completely.

The second aspect that provoked the shift within the movement was the realisation that the secularisation of laws might not be a universal remedy for the situation of all women. The case of Shah Bano herself, who in her fight for maintenance rights came under so much pressure from her own community that ultimately she rejected for herself the maintenance right the court had approved (Menon 2012: 153; Gangoli 2007: 41), revealed a common problem: the conflict of multiple interests, obligations and identities of religious women. The "intersection" of two or more identities is described by Kimberlé Crenshaw. She depicts how belonging to different subordinate groups means being multiply burdened and marginalised (Crenshaw 1989: 140). Furthermore, minority women often feel obliged to choose between the conflicting political agendas that the different groups to which they belong pursue (Crenshaw 1991: 1251-2). Agnes (2012: 36) applies this dilemma to the context of the Muslim woman in India, forced to 
decide between "her claims for gender equality" and "her religious beliefs and community affiliations".

Today the importance of intersectionality is generally accepted among the Indian women's movement. ${ }^{8}$ Regarding the personal laws, however, this paradigm shift has made the struggle for gender justice more complex. Women's rights activists today acknowledge that the problem cannot easily be solved by placing the right to equality in opposition to the freedom of religion and giving the one prevalence over the other through the introduction of a secular Code. In Jenkin's (2009: 927) view, understanding the religious freedom of women "means considering the intersection of gender and religious identities". Sunder Rajan (2008: 80) speaks of a "double commitment" of the women's groups who "cannot confine their struggles to women's interests alone" but must "be sensitive" to minority claims as well.

\section{New Approaches}

While a paradigm shift is clearly visible away from the call for a UCC, there is not as yet a common position regarding what to aim for instead. The 1990s witnessed something of a crisis of the women's movement regarding the personal laws: Lacking a common standpoint, the movement was fragmented with different sub-groups, sometimes battling against each other. While the basic view that all personal laws reveal gender-discriminatory aspects remained, the solutions that were suggested varied. Today, many activists regard the replacement of the personal laws with a Uniform Civil Code (even if termed an Egalitarian Civil Code) a top-down approach, which would harm the interests of religious women and would not be able to change the situation on the ground.

One idea that tries to accommodate both calls for a secular law as well as the interests of religious communities is that of an optional gender-just civil Code. According to this concept ordinarily personal laws would prevail, but people would have the choice to opt for the secular Code, which would ensure gender equality. To a certain degree such an optional Code is already in place with the Special Marriage Act of 1954 (SMA). While this secular law was initially enacted as a provision for interreligious marriages, its mechanism of civil marriage can also be utilised by members of the same faith. This act, it has been suggested, could be taken as a starting point for a secular Code that encompasses other aspects of law and even goes beyond the personal laws, tackling issues such as sexual violence or the economic 
rights of women. A practical model for such an optional Code was drafted in the 1990s by the Forum Against the Oppression of Women (Menon 1998: 258).

Critique of this proposition points out that such an "option" would benefit only a limited number of women. "Given the present imbalance of power and resources", states the women's group Saheli, any law based on such "voluntary" elements is "bound to remain ineffective" (Saheli 1997). Considering this, it has been proposed to "reverse" the element of choice, meaning that the application of the secular and gender-just law would be the norm, while an individual or a couple could voluntarily opt for personal law if they desired. A practical proposal for such a Code has been put forward by the Working Group on Women's Rights. According to this proposal, a comprehensive package of gender-just laws would cover equal rights for women not just within the family but also within a wider scope, for instance, in the sphere of work (WGWR 1996).

An optional UCC would still fulfil the constitutional aspiration of article 44, while at the same time leaving the personal laws in place and therefore acknowledging religious identities. The idea is also attractive as such a Code could go hand in hand with legal reforms of the personal laws as such. As long as these reforms do not take place though, the situation remains problematic. Indira Jaising, founder secretary of the Lawyer's Collective, writes: "if the choice is to be meaningful at all, it must be between gender-just secular law and personal laws that comply with the requirements of equality. Unequal laws ought not to be enforced by the State" (Jaising 2005: 16).

It seems that the dominant position among feminists and women's groups today is that of reforms "from within" the religious communities. Flavia Agnes with her Mumbai-based organisation Majlis was arguably the earliest advocate for this strategy. Later others followed this route. In Agnes' view "small and significant reforms within the personal laws governing minority communities have greater relevance to minority women than the rhetoric of an all-encompassing and overarching Uniform Civil Code (UCC) with its communal undertones" (Agnes 2001: 3973, similarly Rahman 1990: 498).

The left-leaning All India Democratic Women's Association (AIDWA), which initially supported a UCC, now favours a gradual change from within the communities (Murthy and Dasgupta 2011: 129). The Muslim women's organisation Bharatia Muslim Mahila Andolan (2015) pushes for reforms within Muslim personal laws and has drafted a gender-just 
Muslim Family Act. Organisations like Awaaz-e-Niswan and the Women's Research and Action Group in Mumbai, the Confederation of Voluntary Associations (COVA) in Hyderabad, the Muslim Women's Forum in Delhi and the Tamil Nadu Muslim Women's Jamaat have constantly pushed for reforms in Muslim personal law (Murthy \&Dasgupta 2011: 124). Other groups like the Joint Women's Programme have been working with some success to reform the Christian personal laws since the 1980s (ibid.: 129).

While the pitfalls of this approach are its "slow and gradual" transformation (Agnes 2001: 3976) and the danger that in the process of bargaining for reforms with religious community leaders feminist goals might be watered down (Parashar 1992: 229), it seems that the idea of reforms from within is today widely approved among the women's movement. While the gender discriminatory aspects of personal laws and the need for reform are still stressed, the idea that the religious personal laws must be wiped out completely has mostly been abandoned. Legal pluralism is accepted as a fact. Contrary to the argument of earlier days, the reference to the Directive Principle in article 44 is today left aside.

\section{Article 44 in the Decisions of the Supreme Court}

In a number of cases over the last decades the Supreme Court has called for the introduction of a Uniform Civil Code. It refers to article 44 even in cases that do not deal in particular with the personal laws, frequently in obiter dicta, and reminds the legislator of its responsebility under the Directive Principle. The idea of the uniform Code is often connected to topics of national integration, civilisation and development. Only in more recent cases has gender equality featured explicitly as an issue.

However, a more in-depth analysis, especially when keeping in mind that the Indian Supreme Court has been hailed as "the most powerful court in the world" (Jaising 2011: 257; Sathe 2002: 249), reveals a certain reluctance on the part of the court in relation to the area of personal laws. India's Supreme Court enjoys the power of judicial review and a reputation as an independent and activist court (Williams 2006: 162). Public interest litigation has fostered the rights of vulnerable groups of people and has addressed a variety of issues from prisoners' rights and bonded labourers to environmental concerns (Guruswamy and Aspatwar 2013). It has "turned" Directive Principles "into" Fundamental Rights by reading them along the lines of article 
21 , the right to life $^{9}$, and it has given rather precise orders to the government, going so far that some have critiqued it as overstepping its judicial powers (Sood 2008).

Against this background, the court's call for a UCC seems to be mere rhetoric. Not only has the court never declared the personal laws as such unconstitutional, but it has also avoided an in-depth analysis of the constitutionality of particular provisions in specific cases. Indira Jaising speaks of a "hands-off approach" of the judiciary when it comes to the personal laws (Jaising 2000: 290). The court indeed refers to article 44, but at the same time draws a clear line between its own function and the tasks of the legislator or the government (which collectively are often referred to as "the state"). Implicitly it draws on the argument of the separation of powers, making clear that it cannot interfere with the tasks of the two other powers. The question of why it is precisely the area of personal laws that the hands of the court are tied, while in other areas it has exhibited a much more activist stand, remains unanswered. Overall, the following analysis of judgments reveals a strange paradox between the court's call for a UCC on the one hand and a notable reluctance to take any concrete action on the other.

\section{Tentative Reminders}

In a few early cases from the 1970 s and early 1980s the Supreme Court mentioned article 44 among other Directive Principles in order to remind the other two powers of their constitutional obligations. These cases do not deal specifically with personal laws. Rather, Article 44 is mentioned as one example among others. In Kesavananda ${ }^{10}$ (1973) for instance, the court bemoaned that the government "has not been able to take any effective steps" towards the realisation of the UCC, a goal that is "essentially desirable in the interest of the integrity, and unity of the country". At the same time, however, the court declared that the judiciary can "obviously" not "compel the government to lay down a uniform civil code" (ibid.).

The court did something similar in a decision from $1982^{11}$, in which it stressed that article 44 along with other Directive Principles should be "implemented either by the Legislature or by the Executive." Despite seeing possible conflicts between the personal laws and the right to equality, the court did not regard itself as capable or in a position to push for concrete changes. "The only solution for many of these social problems," the court stated, is "to appeal to the appro- 
priate organs of the State to do their assigned job in the best interests of the Community" (ibid.).

Both decisions implicitly drew on the separation of powers. The language the court used is slightly hesitant compared to later cases; the court reminded the other organs rather gently of article 44 . Although there are references to national integrity and the unity of the country, there is no further engagement with these topics.

\section{Communal Undertones: the Shah Bano Case and its Aftermath}

The language of the Supreme Court became much harsher and its call for a UCC became more vehement in the mid-1980s, beginning with the Shah Bano case ${ }^{12}$ from 1985 . The judgment has been controversial, not so much because of the decision itself, but rather because of its language, which unnecessarily links article 44 to the topic of national integration, deploys negative stereotypes against Islam and singles out the helpless situation of Muslim women (Kishwar 1986; Agnes 2011: 157). Similarly as in the two cases cited above, this judgment begins with a general remark, stating that it is "a matter of regret" that article 44 "has remained a dead letter". It then states that a UCC would "help the cause of national integration by removing disparate loyalties to laws which have conflicting ideologies" (Mohd. Ahmed Khan v. Shah Bano Begum). It is clear that here the court is referring to the Muslim community, which, it assumes, has delayed the process of legal unification. Here again, the court calls upon the "state" to have the "political courage" to use its competence for large-scale reforms. Despite regarding the judiciary as a "reformer"-and hereby granting itself a stronger position than in the earlier cases-the court nevertheless clarifies that itself should not step in and make "piecemeal" attempts at changes through case law.

The court does refer to gender inequality under the personal laws, when it points out that "large segments of society $[\ldots]$ have been traditionally subjected to unjust treatment. Women are one such segment" (ibid.). It further states that the case at hand raises issues of general interest, which are of relevance "not only to Muslim women, not only to women generally but, to all those who, aspiring to create an equal society of men and women, lure themselves into the belief that mankind has achieved a remarkable degree of progress in that direction" (ibid.). As positive as this gender sensitive reference might appear at first sight, the anti-Muslim bias, on which the judgment draws, fosters the impression that it is not a feminist position that is 
put forward here. Rather, the plight of the Muslim woman is used to defame Muslim personal law as "ruthless in its inequality" (ibid.). In fact, neither article 14 nor the right to equality is mentioned in the decision. Instead, the judgment draws on the development argument and deploys an image of societal progress from an unjust to a just society in which the UCC would help as a vehicle to foster this development.

Only one month after the judgment in the Shah Bano case, the Supreme Court dealt with the UCC again. Ms Jordan Diengdeh v. S.S. Chopra ${ }^{13}$ concerned the constitutionality of the Hindu Marriage Act. The judgment begins with a reference to Shah Bano and an emphasis on the "urgency of infusing life into Art. 44". The lack of a Uniform Civil Code is described as a "totally unsatisfactory state of affairs" (ibid.). The court held: "Surely the time has now come for a complete reform of the law of marriage and make a uniform law applicable to all people irrespective of religion or caste" (ibid.). It remains unclear why it is precisely "now" that the time has come to begin drafting a UCC. The period following the Shah Bano decision was a time of communal tension with sharp confrontations between the Muslims and the Hindus and between society and the state. However, the court seems to take the issue of the UCC more seriously here when demanding that a copy of its order "may be forwarded to the Ministry of Law and Justice for such action as they may deem fit to take" (ibid.).

In 1994, the petitioners in Maharshi Avadhesh $v$. Union of India ${ }^{14}$ asked the court to "consider the question" of the enactment of a UCC as well as to declare the Muslim Women Act unconstitutional. Notably, this writ petition was dismissed immediately with the argument that "[t]hese are all matters for legislature. The Court cannot legislate in these matters". ${ }^{15}$ Why the court is not able to examine the constitutionality of the MWA remains unclear. It seems that the separation of powers argument is deliberately used as an excuse not to deal with the constitutionality of the personal laws. The judgement later became an important reference point when the court declared itself incompetent to decide upon matters regarding the UCC. It is, for instance, quoted in Ahmedabad Women Action Group ${ }^{16}$ (1997), in which a number of women's rights groups asked the Supreme Court to declare several aspects of the Muslim personal law unconstitutional. This promising case, in which different interest groups intended to litigate strategically in order to bring about a landmark decision, was unsuccessful. 
Another decision regarding article 44, which is often cited as an example of the communal bias of the court, is Sarla Mudgal v. Union of India $^{17}$ (1995). In this case the Supreme Court had to decide whether a married Hindu man who converts to Islam can legitimately marry a second wife as permitted under Muslim personal law. The judgment begins with a citation of article 44 and dedicates a whole paragraph to a critique of the government with regard to its reluctance to introduce a UCC. The "[r]ulers of the day", the court bemoans, were apparently "not in a mood to retrieve Article 44 from the cold storage where it is lying since 1949" (ibid.). In a similar fashion as in Shah Bano, the judgment defames Muslim personal law and draws on the well-known stereotype that while the Hindus had willingly reformed their laws, the Muslims would be reluctant to follow suit. But it goes further than this. Deploying an idea of a scale of development and drawing a link between secularism and civilisation, the judgment states: "Article 44 is based on the concept that there is no necessary connection between religion and personal law in a civilised society" (ibid.). Furthermore, taking up a discourse that the Hindu nationalists have long used as a warning to Indian Muslims, the judgement states: "Those who preferred to remain in India after the partition", knew that "in the Indian Republic there was to be only one Nation" and hence, "no community could claim to remain a separate entity on the basis of religion".

Feminist authors like Agnes (2011: 163) have criticised the judgement's language as pitting those who oppose the UCC (allegedly the Muslims) against the rest of "the Indian Nation". It is also interesting to note that while the 14-page judgement uses the term "uniform" 18 times and "uniform civil code" 10 times, it only uses the term "women" twice, and does not refer to "gender", "equality" or article 14 at allanother indication of the sharp contrast in argumentation between the women's movement and the court.

\section{Rethinking?}

More recent judgments provide a mixed picture of the court's standpoint. While in a decision from the 1990s, the court tentatively declared some scepticism regarding whether the UCC was a feasible option and thereby hinted at a shift in its position, in later cases the court went back to its earlier call for a common Code. Its earlier position-that "piecemeal" changes through court intervention would 
not be helpful-was partly revised, when the court declared parts of the Christian personal law explicitly unconstitutional.

In Pannalal Bansilal Pitti ${ }^{18}$ (1996), the court indeed still held the viewpoint that a UCC was desirable but questioned its feasibility. It referred to the pluralist character of the Indian society and argued that the constitution itself tries to balance diversity and uniformity. The enactment of a Uniform Civil Code, though "highly desirable" may "perhaps [...] be counter-productive to unity and integrity of the nation" if pushed through "in one go" (ibid.). This reasoning is interesting, as the argument of "unity and integrity of the nation"-usually used by proponents of the UCC-is here used as a counter argument. The top-down approach of an all-encompassing legislation is regarded as problematic. Rather, the country should strive for "gradual progressive change" (ibid.). In a "slow process" the legislature should attempt "to remedy where the need is felt most acute" (ibid.). This reasoning resembles the propositions of women's rights groups of more recent times outlined above. A similar argument was later, in 2001, made in the Danial Latifi case ${ }^{19}$, where the Supreme Court held that it is not unreasonable in Indian law to make distinctions based on community membership.

A case that is seen as a landmark decision followed in 2002, when the court in John Vallamattom ${ }^{20}$ engaged with the constitutionality of Christian personal law. After earlier hesitations, the court positioned itself more clearly, but at the same time deployed the old stereotypes. The topic of the UCC is taken up at the end of the judgment, with the Sarla Mudgal-argument that there is "no necessary connection between religious and personal law in a civilized society". The parliament is called to "step in for framing a common civil code in the country" as such a Code would "help the cause of national integration by removing the contradictions based on ideologies" (ibid.). The court here allows the writ petition and declares the specific provision, Section 118 of the Indian Succession Act, "unreasonable", "arbitrary and discriminatory and, therefore, violative of Article 14 of the Constitution" (ibid.). On the one hand, in this decision the court was more courageous than in earlier cases, where it simply avoided an engagement with the constitutionality of personal law provisions. On the other hand, the case again reveals communal undertones with its reference to "national integration" and the "civilised society".

Finally, in two recent cases, the court again referred to article 44 . In a case from $2014^{21}$, it deals with the right to adopt and be adopted 
under the Juvenile Justice (Care and Protection of Children) Act, 2000. To the court, this act is "a small step in reaching the goal enshrined by Article 44" (ibid.). While holding that "[p]ersonal beliefs and faiths must be honoured", the court stressed the importance of secular legal options "until such time that the vision of a uniform Civil Code is achieved" (ibid.). In a case from $2015^{22}$, the court dealt with the topic of a mother's guardianship for her child born out of wedlock. Fostering the rights of single mothers, the court also commented on the personal law and on the UCC more generally, stating that "India is a secular nation and it is a cardinal necessity that religion be distanced from law" and "underscoring" that the Directive Principles envision a Uniform Civil Code (ibid.).

\section{Comparative Thoughts Beyond Rhetoric}

This paper has analysed the discourse around article 44 within two different entities: the women's movement and the Indian Supreme Court. It has juxtaposed what the Uniform Civil Code means for these two actors and revealed that while initially there was a call for the UCC from both the women's movement as well as the court, the former has undergone a radical shift in its position and rhetoric while the latter has to a greater or lesser extent maintained its position, at least on a rhetorical level. This last part of the paper will compare and contrast the discourses among the two protagonists and look beyond the level of mere rhetoric.

\section{Reading the Signs of the Times}

The discussion above has demonstrated that the two entities today have very different standpoints. The women's movement has within the past 40 years flip-flopped its position. Earlier deeming the UCC a universal remedy for discrimination against women, it now regards the Code as a threat. It is sceptical about the feasibility of a legislative topdown approach and prefers other options to achieve gender justice, in particular reforms from within the religious communities. The Supreme Court has maintained its position to a greater or lesser extent, and time and again has called for the introduction of a UCC. The paper has further shown that the discourse of the two entities revolves around very different arguments: The women's movement in its engagement with the personal laws draws on the right to equality. Women's groups also explicitly distance themselves from the position and rhetoric of the BJP. They deploy a different rhetoric, speaking for instance of an 
Egalitarian rather than a Uniform Civil Code in order to make clear that they do not affiliate with the Hindu nationalists. The Supreme Court, on the other hand, draws on arguments of national integration, civilisation, secularism and modernity, and thereby deploys a similar rhetoric to that of the Hindu nationalists, frequently even using biased statements against the Muslim community.

Against the background of a global paradigm shift towards the acceptance of legal pluralism, this poses significant questions. Has the women's movement seen the signs of the time more clearly than the court? Is the movement more realistic than the court in its scepticism towards top-down legislative approaches? Has it walked on while the Supreme Court has held onto a concept of modernity from the middle of the last century? Today's goals are certainly different from the goals of the 1940s; modernity is no longer necessarily defined through legal uniformity and today's means to achieve social change are different from the means of the past. Has the women's movement understood and accepted this while the court has not?

As has been demonstrated, the shift in the position of the women's movement is partly due to the movement's worry that a further call for the UCC would foster the BJP's alleged project of a "Hindu Code." Therefore, to a certain degree, the movement has pulled back out of fear rather than changed its position due to a deliberate reconsideration. The incoherence of the different positions among the movement during the 1990s illustrates this very well. But there are also other reasons for the parading shift among the movement. Its own often frustrating experience with the non-implementation of state laws on the ground and the increased awareness of intersectionality have led the movement to the understanding that other options might be more constructive than the top-down enactment of an all-encompassing UCC.

Feminists and women's groups today are calling for the expansion of the already existing secular laws and their better implementation in order to protect women's rights. Furthermore, they propose to work out reforms of the personal laws in collaboration with religious community leaders and the communities more broadly. While this ground level approach is certainly slow, it might well be a more successful strategy. In the delicate area of personal laws, which is closely linked to identity politics, this approach respects the interests of the communities and is therefore more accepted. This was well demonstrated by the reforms on divorce provisions within the Christian 
personal laws in 2001. In this sense, the women's movement is following the global trend towards accepting legal pluralism as a fact and working with it. The court, it seems, has missed this trend. But maybe a closer look is necessary here.

\section{Lip Service to the Constitution}

At least on a rhetorical basis, the Supreme Court has kept its pro-UCC position throughout the decades, calling upon the legislator to introduce the uniform Code. On the other hand, it has never gone as far as to declare the personal law system as such unconstitutional. On the contrary, in the ambit of the religion-based laws, the Supreme Court has not exhibited the same activist stand that it has demonstrated in other areas. Instead, it has frequently played the ball back to the legislator, implicitly drawing on the argumentation of separation of powers (which it seems not to take as seriously when it comes to other aspects of the legal landscape). The court has even been criticised as deploying "avoidance strategies" when engaging with the personal laws (Jaising 2005).

To be sure, it is beyond the capacity and the tasks of the court to draft a Code itself. But comparing the above-mentioned decisions with other case law and bearing in mind the activist role of the court, which elsewhere has strengthened the importance of Directive Principles, the court seems rather reluctant in this area. Why was the court not more radical in striking down as unconstitutional those parts of the personal laws that contradict the right to equality? Why did it not set the legislator a time limit for the drafting of a UCC? Why did it not stipulate concrete guidelines for such a Code? The court's call for a UCC remains largely undifferentiated. Questions such as what that Code should encompass, who should be involved in the drafting process, which values should be included, and how it should be ensured that the rights and identities of minorities and women are adequately respectted, are neither posed nor answered in the court's decisions. Had the court taken the idea of the UCC seriously, one might reason, it would have pushed it further. Its reluctance to exhibit more concrete action shows that it does not give priority to the matter.

This reluctance to go beyond mere rhetoric could have different root causes. It could be that the personal laws are simply too hot a topic. The personal laws are closely linked to community identity. The court might fear communal backlashes if it were to strike down elementary parts of those laws, which for many people form a crucial marker of 
identity. The Shah Bano case demonstrated how easily communal tension and riots are provoked. Hence, the court might be trying to avoid further stirring up this critical issue. However, this argumenttation does not fit well with the fact that the court itself so frequently uses an anti-minority rhetoric. In Shah Bano it was more the language than the decision itself that provoked the backlash. Two cases ${ }^{23}$ before Shah Bano were actually decided in a very similar manner without using such biased language and hence were broadly accepted. Therefore, the argument that the Supreme Court avoids provocation is not entirely convincing.

Another explanation for why the court refrains from pushing for further action in this area might be that in actual fact it has accepted legal pluralism itself. It might, just like the women's movement, regard a top-down legislative approach as problematic. This argumentation is supported by the fact that the Indian judiciary today practices a lot of small-scale reform on a case-by-case basis, as is further explained below. If the Supreme Court itself does not believe in the UCC any more, then the question remains, however, as to why on a rhetorical level it still calls for it. Why is this pseudo-call for a UCC deployed without putting the rhetoric further into action?

Here it is certainly the different aims and tasks of the two entities and the different expectations towards them that shed light on the issue. The women's movement is a political player. It conducts interest politics for a certain interest group. It can ask for whatever it wishes. Hence, it can ignore article 44. It reacts to international trends and changes in feminist scholarship, such as the idea of intersectionality. The Supreme Court, on the other hand, is a state organ entrusted with the interpretation of the constitution. Article 44 is part of the constitution and hence must be taken into account-if only by paying lip service to it. The analysis of the cases above seems to demonstrate just that: the Supreme Court pays lip service to the constitution by calling for the introduction of a Uniform Civil Code while at the same time not pushing the implementation any further.

\section{The Essence of Article 44}

If legal pluralism as a concept is accepted by the women's movement and by the Indian Supreme Court as well as more broadly, does this consequently mean that article 44 is a "dead letter" as the Court called it in the Shah Bano case? One could certainly regard it as a constitutional idea of the mid-20th century that has not survived to the 
present day. The idea of uniformity of laws as a prerequisite to modernity is questionable today. The enactment of a UCC for the whole Indian territory seems currently unlikely. The several draft codes prepared by women's groups and academics in the 1980s and 1990s have not been realised. Today, despite the fact that the BJP mentioned the enactment of the uniform Code in its election manifesto and-in terms of the current composition of parliament-could probably push this project through, the Modi government has mostly been quiet on the issue. Werner Menski (2006: 52) describes the call for a UCC, if understood as an abolition of the personal laws and the complete restructuring of the Indian legal system, as "asking for the moon, totally unrealistic and simply not feasible." In this sense the UCC is dead.

Nevertheless, the debate around the reform of personal laws continues. The women's movement is still engaged in finding ways to provide for gender justice. And the judiciary is challenged time and again with the interpretation of personal law provisions. Hence, the question is whether the essence of article 44 is actually being brought about through other means than through an all-encompassing Code.

Women's groups often work in a threefold manner: firstly, they lobby for the enactment or amendment of specific legal provisions on the state level; secondly, they litigate cases in order to challenge problematic provisions in court and push for new and better case law; and thirdly, they work on the ground in collaboration with communities. Through this holistic approach the women's movement has provided for gender justice in a variety of areas. Not only that, it has also pushed for an assimilation of the personal laws by other means. This activism is part of what Sezgin calls a "revolution [...] in the personal status system of many postcolonial nations" coming about "as a result of a grand bargaining between progressive and conservative forces in each society" (Sezgin 2010a: 29-30).

In this step-by-step revolution, the judiciary plays a central role too. In the Shah Bano decision the court held that "piecemeal attempts of courts to bridge the gap between personal Laws cannot take the place of a common Civil Code. Justice to all is a far more satisfactory way of dispensing justice than justice from case to case". But looking at the present day reality and at the judiciary more broadly, it seems that it is precisely these piecemeal attempts that have occurred throughout the last decades. Agnes (2011), Subramanian (2014) and Serajuddin (2015 \&2011) show how courts exhibit step-by-step activism, which 
makes the legal world in the area of personal laws more gender just and at the same time assimilates the personal laws more and more. Courts in this sense function as quasi legislators in a trend of juristocracy (Hirschl 2004). In the delicate context of personal laws, this step-by-step activism might actually be a more efficient way to achieve change without provoking communal backlashes.

Hence, personal laws are being amended through holistic cooperation between different actors in the state. In Menski's words, "India has devised a strategy of carefully planned minor changes over a long span of time" through an "intricate interplay between judicial activism and parliamentary intervention" (Menski 2008: 218). The argument here is that slowly the various personal laws have been made more and more similar, and are today in effect largely harmonised, though they remain formally different. In this way, India has found a "mirror image" of the UCC (Menski 2008: 213). Consequently, article 44 is still very much alive, in the sense that its essence-uniformity and equality-is provided through other means.

\section{Endnotes}

* This article has previously been published in Verfassung und Recht in Übersee 49 (2016) 2, 14874. The author would like to thank Professor Philipp Dann and Professor Werner Menski for their support, guidance and input in the research and writing of this article.

${ }^{1}$ Parashar criticises the terminology of "laws" in this context. She argues that scholars who label the various customs and social practices as "law" would achieve an "implied immunity from questioning of those practices because they are law" and thereby enable "institutional discrimination" (Parashar 2013: 17). The following analysis, however, will show how personal laws-despite being labelled "laws"-are indeed severely criticised and contested (especially by the women's movement) and as a consequence sometimes amended.

${ }^{2}$ In Mohini Jain v. State of Karnataka and others (1992) 3 SCC 666 and Unii Krishnan J.P. and others v. State of Andhra Pradesh and others (1993) 1 SCC 645 the Supreme Court held that the right to education is a Fundamental Right enshrined in Article 21 of the constitution.

${ }^{3}$ The State of Bombay v. Narasu Appa Mali, AIR 1952 Bom 84.

${ }^{4}$ C. Masilamani Mudaliar \& Ors v. The Idol of Sri Swaminathaswami Thirukoil, 1996 AIR, 1697.

${ }^{5}$ Mohd. Ahmed Khan v. Shah Bano Begum and Ors, AIR 1985 SC 945.

${ }^{6}$ One of the active advocates of a UCC was the All India Women's Conference (AIWC), arguably the oldest national women's organisation, founded in 1927 (Agnes 2011, 149, Parashar 1992, 230).

7 1974. Towards equality: report of the Committee on the Status of Women in India http://pldindia.org/wp-content/uploads/2013/04/Towards-Equality-1974-Part-1.pdf [retrieved 27.4.2016]. 
${ }^{8}$ The 7th national conference of the women's movement held in 2006 in Kolkata, for instance, stressed that "social constructs such as caste, class, religion, ethnicity, disability and sexuality create multiple identities" for many women.

www.openspace.org.in/node/173 [retrieved 27.4.2016].

${ }^{9}$ See Endnote 1.

${ }^{10}$ Kesavananda Bharati v. State Of Kerala And Anr, 1973, Judgment W.P.(c) 135 of 1970.

${ }^{11}$ National Textile Workers V. P.R. Ramkrishnan and Others, 1982, AIR 75.

12 Mohd. Ahmed Khan v. Shah Bano Begum and Ors, AIR 1985 SC 945.

${ }^{13}$ Ms Jordan Diengdeh v. S.S. Chopra, 1985 AIR 935.

${ }^{14}$ Maharshi Avadhesh v. Union of India, 1994 SCC, Supl. (1) 713.

${ }^{15}$ The Muslim Women's Act is later declared constitutional in Danial Latifi \& Anr vs Union of India, (2001) 7 SCC.

${ }^{16}$ Ahmedabad Women Action Group vs Union of India, JT 1997 (3) SC 171.

${ }^{17}$ Sarla Mudgal v. Union of India (1995) 3 SCC 635.

${ }^{18}$ Pannalal Bansilal Pitti \& Ors. Etc v. State Of Andhra Pradesh \& Anr, 1996 SCC (2) 498.

${ }^{19}$ Danial Latifi \& Anr v. Union of India, (2001) 7 SCC.

${ }^{20}$ John Vallamattom And Anr v. Union Of India, JT 2003 (6) SC 37.

${ }^{21}$ M/S Shabnam Hashmi v. Union of India \& Ors on 19 February 2014.

${ }^{22}$ Abc v. State, on 6 July 2015.

${ }^{23}$ Bai Tahira A. v. Ali Hussain Fissalli Chothia, 1979 AIR 362 and Fuzlunbi v. K. Khader Vali \& Anr., AIR 1980 SC 1730.

\section{Bibliography}

Agnes, Flavia. 2012. From Shah Bano to Kausar Bano: contextualizing the 'Muslim woman' within a communalized polity. In: Ania Loomba \& Ritty A. Lukose, eds. South Asian feminisms. Durham: Duke University Press, pp. 33-53 . 2011. Family law volume I: family laws and constitutional claims. New Delhi: Oxford University Press.

. 2001. Minority identity and gender concerns. Economic and Political Weekly, 36 (42), pp. 3973-6.

Agnihotri, Indu. 2001. Re-reading histories. Seminar, 505.

Andolan, Bharatiya Muslim Mahila. 2015. Muslim family law Belgaum: Omega Publications.

Austin, Granville. 2001. Religion, personal law, and identity in India. In: Gerald James Larson, ed. Religion and personal law in secular 
India: a call to judgment. Bloomington: Indiana University Press, pp. 15-23.

Baird, Robert D. 2005. Religion and law in India: adjusting to the sacred as secular. In: Robert D. Baird, ed. Religion and law in independent India. New Delhi: Manohar, pp. 8-34

Bajpai, Rochana. 2011. Debating difference: group rights and liberal democracy in India. New Delhi: Oxford University Press.

Crenshaw, Kimberlé W. 1989. Demarginalizing the intersection of race and sex: a black feminist critique of antidiscrimination doctrine, feminist theory and antiracist politics. The University of Chicago Legal Forum, 1998, pp. 139-67.

Crenshaw, Kimberlé W. 1991. Mapping the margins: intersectionality, identity politics, and violence against women of color. Stanford Law Review, 43, pp.1241-99.

Das Basu, Durga. 2013. Introduction to the constitution of India. $21^{\text {st }}$ ed. Gurgaon: Lexis Nexis.

De, Rohit. 2013. Personal laws: a reality check. Frontline, 6 Sept. 2013.

Derrett, J. Duncan M. 1957. Hindu law, past and present. Calcutta: A. Mukherjee.

Dhavan, Rajeev. 2001. The road to Xanadu: India's quest for secularism. In: Gerald James Larson, ed. religion and personal law in secular India : a call to judgment. Bloomington: Indiana University Press, pp. 301-29.

Gangoli, Geetanjali. 2007. Indian feminisms: law, patriarchies and violence in India. Aldershot: Ashgate.

Guruswamy, Menaka \& Bipin Aspatwar. 2013. Access to justice in India: the jurisprudence (and self-perception) of the Supreme Court. In: Daniel Bonilla Maldonado, ed. Constitutionalism of the global south: the activist tribunals of India, South Africa, and Colombia. Cambridge: Cambridge University Press, pp. 329-59.

Hirschl, Ran. 2004. Towards juristocracy: the origins and consequences of the new constitutionalism. Cambridge: Harvard University Press.

Jaising, Indira. 2011. An outsider, inside. In: Ritu Menon, ed. Making a difference: memoirs from the women's movement in India. New Delhi: Women Unlimited, pp. 347-69. 
. 2005. Gender justice: a constitutional perspective. In: Indira Jaising, ed. Men's laws, women's lives: a constitutional perspective on religion, common law and culture in South Asia. New Delhi: Women Unlimited, pp. 1-22.

. 2000. Gender justice and the Supreme Court. In: B.N. Kirpal et. al., eds. Supreme but not infallible: essays in honour of the Supreme Court of India. New Delhi: Oxford University Press, pp. 288-320.

Jenkins, Laura Dudley. 2009. Diversity and the constitution in India: what is religious freedom? Drake Law Review, 57 (4), pp. 913-47.

Kishwar, Madhu. 1993. Breaking the stalemate: Uniform Civil Code vs. Personal Law. Manushi, 77, pp. 2-5.

. 1986. Pro women or anti Muslim? The Shah Bano controversy. Manushi, 32, pp. 4-13.

Krishnaraj, Maithreyi. 1998. Women and the public domain: critical issues for women studies. Economic and Political Weekly, 33 (8), pp. 391-5.

Kumar, Radha. 1993. A history of doing: an illustrated account of movements from women's rights and feminism in India 18001990. New Delhi: Kali for Women.

Mann, Michael. 2007. Rechtsauslegung im kolonialen Indien: islamisches Recht und Hindu Recht unter britischer Rechtsprechung, 1765-1864. In: Georg Berkemer \& Gita Dharampal-Frick, eds. Schriftenreihe Elektronische Veröffentlichungen zur Geschichte Südasiens. Heidelberg.

Mansfield, John H. 2005. The Personal laws or a Uniform Civil Code? In: Robert D. Baird, ed. Religion and law in independent India. New Delhi: Manohar Publishers, pp. 207-45.

McCammon, Holly J. \& Allison R. McGrath. 2015. Litigating change? Social movements and the court system. Sociology Compass, 9 (2), pp. 128-39.

Menon, Nivedita. 2012. Seeing like a feminist. New Delhi: Zubaan, Penguin.

. 1998. Women and citizenship. In: Partha Chatterjee, ed. Wages of freedom: fifty years of the Indian nation-state. Delhi: Oxford University Press, pp. 241-66. 
Menski, Werner. 2008. The Uniform Civil Code debate in Indian law: new developments and changing agenda. German Law Journal, 9 (3), pp. 211-50.

. 2006. Asking for the moon: legal uniformity in India from a Kerala perspective. Kerala Law Times, Journal Section, 2, pp. 5278.

. 2003. Hindu law: beyond tradition and modernity. New Delhi: Oxford University Press.

Mullally, Siobhan. 2004. Feminism and multicultural dilemmas in India: revisiting the Shah Bano case. Oxford Journal of Legal Studies, 24 (4), pp. 671-92.

Murthy, Laxmi \& Rajashri Dasgupta. 2011. Our pictures, our words: a visual journey through the women's movement. New Delhi: Zubaan.

Parashar, Archana. 2013. Religious personal laws as non-state laws: implications for gender justice. The Journal of Legal Pluralism and Unofficial Law, 45 (1), pp. 5-23.

. 2005. Just family law: basic to all Indian women. In: Indira Jaising, ed. Men's laws, women's lives: a constitutional perspective on religion, common law and culture in South Asia. New Delhi: Women Unlimited, pp. 286-322.

. 1992. women and family law reform In India: Uniform Civil Code and gender equality. New Delhi: Sage Publications.

Rahman, Anika. 1990. Religious rights versus women's rights in India: a test case for international human rights law. Columbia Journal for Transnational Law, 28, pp. 473-98.

Saheli. 1997. An egalitarian Civil Code: every woman's basic right. . 1995. Egalitarian Civil Code: an Iisue of gender justice. . 1986. Towards a Uniform Civil Code.

Sathe, S. P. 2002. Judicial activism in India: transgressing borders and enforcing limits. $2^{\text {nd }}$ edn. New Delhi: Oxford University Press.

Schneider, Nadja-Christina. 2005. Zur Darstellung von "Kultur" und "kultureller Differenz" im indischen Mediensystem: die indische Presse und die Repräsentation des Islams im Rahmen der Zivilrechtsdebatte, 1985-87 und 2003. Berlin: Logos. 
Sen, Rukmini. 2014. Mapping women's activism in India: resistances, reforms and (re)-creation. In: Leela Fernandes, ed. Routledge handbook of gender in South Asia. Abingdon: Routledge, pp. 33346.

Serajuddin, Alamgir Muhammad. 2015. Cases on Muslim law of India, Pakistan and Bangladesh. New Delhi: Oxford University Press. . 2011. Muslim family law, secular courts and Muslim women of South Asia: a study in judicial activism. Karachi: Oxford University Press.

Sezgin, Yüksel. 2010a. How to integrate universal human rights into customary and religious legal systems? The Journal of Legal Pluralism and Unofficial Law, 42 (60), pp. 5-40.

. 2010b. Introduction to the special issue. The Journal of Legal Pluralism and Unofficial Law, 42 (60), pp. 1-4.

Sood, Avani Mehta. 2008. Gender justice through public interest litigation: case studies from India. Vanderbilg Journal of Transnational Law, 41 (3), pp. 833-906.

Subramanian, Narendra. 2014. Nation and family: personal law, cultural pluralism, and gendered citizenship. Stanford: Standford University Press.

Sunder Rajan, Rajeswari. 2008. Women between community and state: some implications of the Uniform Civil Code debates. In: Janet R. Jakobsen \& Ann Pellegrini, eds. Secularisms. Durham: Duke University Press, pp. 76-107.

WGWR. 1996. Reversing the option: civil codes and personal laws. Economic and Political Weekly, 31 (20), pp. 1180-3.

Williams, Rina Verma. 2006. Postcolonial politics and personal laws: colonial legacies and the Indian state. New Delhi: Oxford University Press. 